\title{
Transformation of a Marine Toxic Polyether, Okadaic Acid
}

\author{
Yoshiyasu ICHIKAwa, ${ }^{*}$ Minoru IsobE** and Toshio Goto \\ Laboratory of Organic Chemistry, Faculty of Agriculture, \\ Nagoya University, Chikusa, Nagoya 464, Japan \\ Received October 26, 1987
}

\begin{abstract}
Natural okadaic acid 1 was transformed into the 7,24,27-tri-O-benzyl-1,2-acetonide derivative (4) in a $66 \%$ overall yietd. The corresponding synthetic derivative (4) was identified with this authentic sample.
\end{abstract}

In 1981, okadaic acid was isolated from two kinds of sponges, Halicondria okadai along the Pacific coast of Japan, and Halilcondria melanodocia in the Florida Keys. ${ }^{1)}$ The structure of okadaic acid was elucidated by Tachibana $e t$ al. ${ }^{1)}$ as (1) through X-ray crystallographic analysis of an $o$-bromobenzyl derivative. This molecule comprised a backbone with 38 -carbon atoms, 17 asymmetric centers, 4 hydroxy groups, 6 methyl groups and 3 types of olefins. Yasumoto et al. disclosed that okadaic acid was identified to be a diarrhetic shellfish toxin in $1982 .{ }^{2)}$ The first total synthesis of this toxin was reported from this laboratory in $1986 .{ }^{3}$ In this synthesis, we confronted the problem of protection and deprotection of the hydroxy groups. ${ }^{4)}$

Benzyl ethers were chosen for protecting the hydroxy groups at the C-7, C-24, and C-27 positions, the corresponding tri-benzyl ethers (4), (5), (6) and (7) having been from natural okadaic acid. ${ }^{3)}$ Tribenzyl okadaic acid (5) was subjected to a debenzylating condition such as lithium metal in liquid ammonia. Although it had been planned to remove the benzyl protection by the alkali metal, the removal was accompanied by serious over-reduction products in the synthetic study. These were considered to be a mixture of reduction at the $\mathrm{C} 2$ $\mathrm{OH}$ next to carboxylic acid and at the allyl ethers at the C-8, C-16, C-24 and C-26 positions. When the tri-benzyl 4 was reduced with lithium in liquid ammonia at $-78^{\circ} \mathrm{C}$, the product was isolated, but showed absence of the peak corresponding to the allylic $\mathrm{H}-16$ proton at around $\delta 4.5$ in the ${ }^{1} \mathrm{H}-\mathrm{NMR}$ spectrum. This result revealed that the hydrogenolysis took place at the allylic $\mathrm{C} 16-\mathrm{O}$ bond. Systematic studies on debenzylation were necessary to find a kinetic condition in which the velocity of hydrogenolysis could be made even less than that of debenzylation. This paper deals with studies to solve these problems by the transformation of natural okadaic acid, which was only obtained in a limited amount.

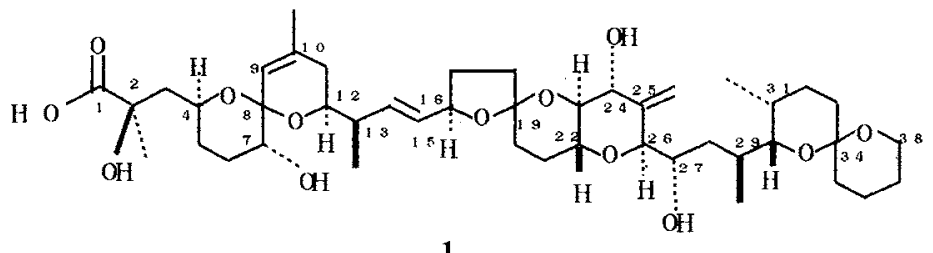

1

* Present address: Faculty of Education, Mie University, 1515 Kamihama, Tsu 514, Japan.

** To whom correspondence should be addressed. 


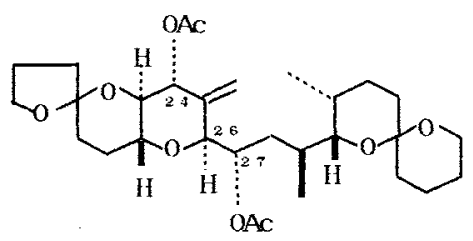

2

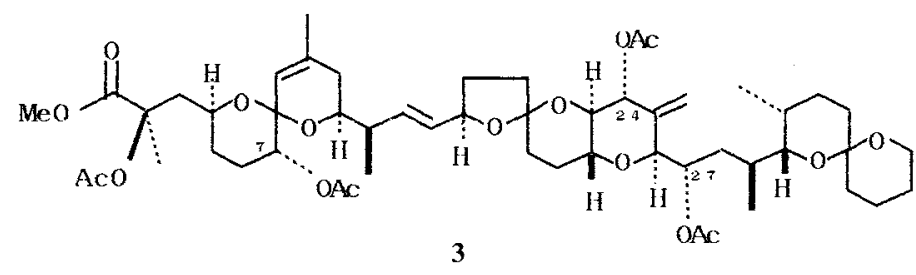

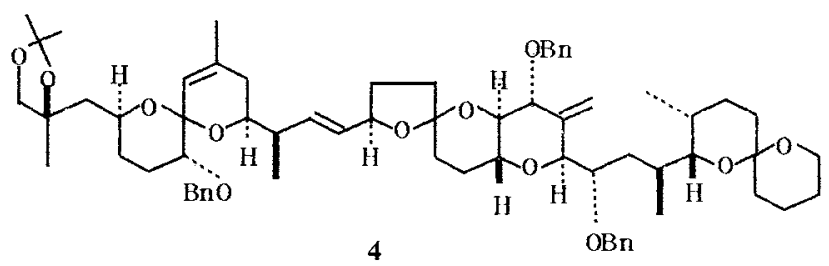

Preparation of the tri-benzylether of okadaic acid and debenzylation

Three hydroxy groups at the C-7, C-24 and C-27 positions of okadaic acid (1) were protected as its benzyl ether by treating with benzyl bromide and sodium hydride in a mixture of tetrahydrofuran (THF) and $N, N$ dimethylformamide (DMF). This condition allowed no benzylation at the tertiary $\mathrm{C} 2-\mathrm{OH}$, and furnished tribenzyl okadaic acid (5) in a $47 \%$ yield.

We attempted to remove the benzyl groups with 5 but this was accompanied by overhydrogenolysis (vide supra). This problem was finally solved by introducing a small amount of lithium metal into 5 at $-78^{\circ} \mathrm{C}$. Stirring the mixture for 30 min provided okadaic acid (1) ${ }^{5}$ ) The product was converted into the methyl ester with diazomethane in methanol, purified on TLC (in an $80 \%$ yield from 4), and then identified with the authentic okadaic acid methyl ester.

Debenzylation of tribenzyl okadaic acid (5) gave crystalline okadaic acid (1) from hot hexane. ${ }^{6)}$ Both of the okadaic acids were com- pletely identical from their $500 \mathrm{MHz}{ }^{1} \mathrm{H}-\mathrm{NMR}$ spectra.

Preparation of the tribenzyl acetonide (4) and confirmation of its stereochemistry

Okadaic acid (1) has 4 asymmetric centers on acyclic parts at the C-2, C-13, C-27 and C29 positions. ${ }^{1} \mathrm{H}-\mathrm{NMR}$ spectroscopic analysis had already confirmed the stereochemistry of the synthetic intermediates at C-2, C-13 and C$29 .{ }^{7)}$ The asymmetric center at $\mathrm{C}-27$ was to be confirmed, since it was induced by reduction of the corresponding ketone. The stereochemistry has been assumed on the basis of a mechanism controlled by steric and electronic effects, ${ }^{8)}$ and a direct comparison of the synthetic and natural speciments was necessary. A closer comparable specimen was synthesized by converting natural okadaic acid (1) to the tetraacetate methyl ester with acetic anhydride in pyridine, and then with diazomethane in methanol.9) This compound from the natural source was compared with the synthetic model compound (2) prepared from D-glucose derivatives in 37 steps. $^{10)}$ The chemical shift and 
coupling constant of the hydrogen at C-27 of okadate $(3)(\delta 5.59$, ddd, $J=11,9,2$; see Fig. $2(\delta 5.60, \mathrm{ddd}, J=12,9,2 \mathrm{~Hz})$ was identical 1$)$. to that of methyl 2,7,24,27-tetra- $O$-acetyl- Such a comparison was also examined on
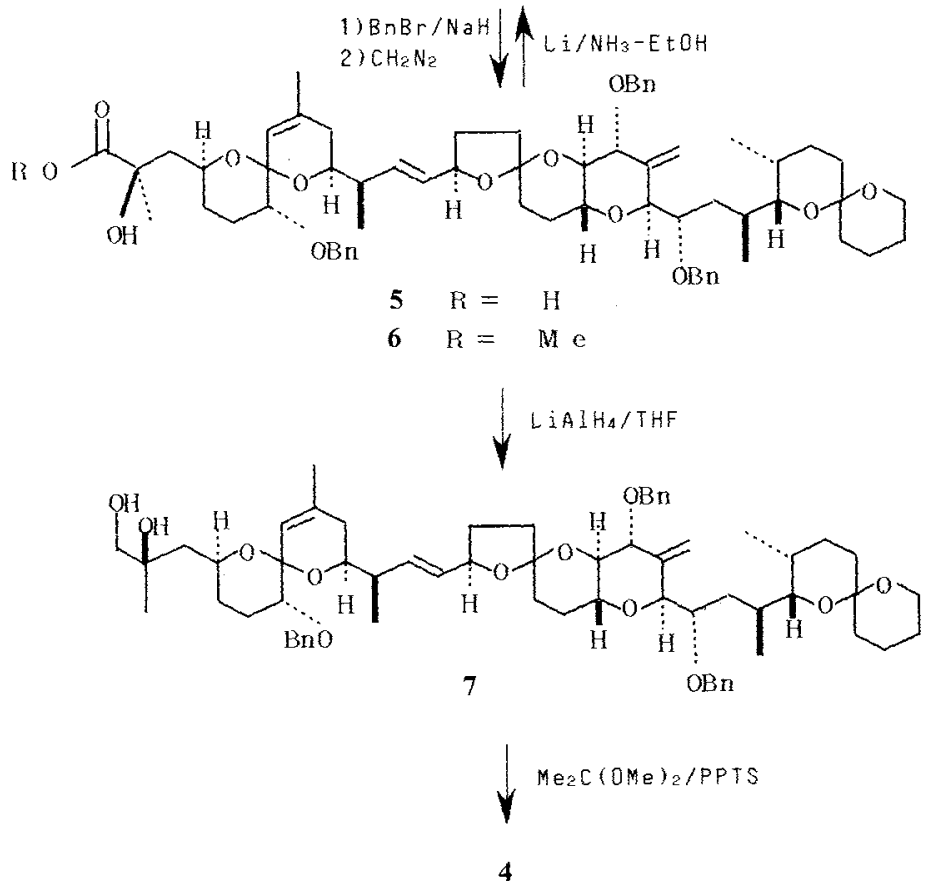

SCHEME 1.

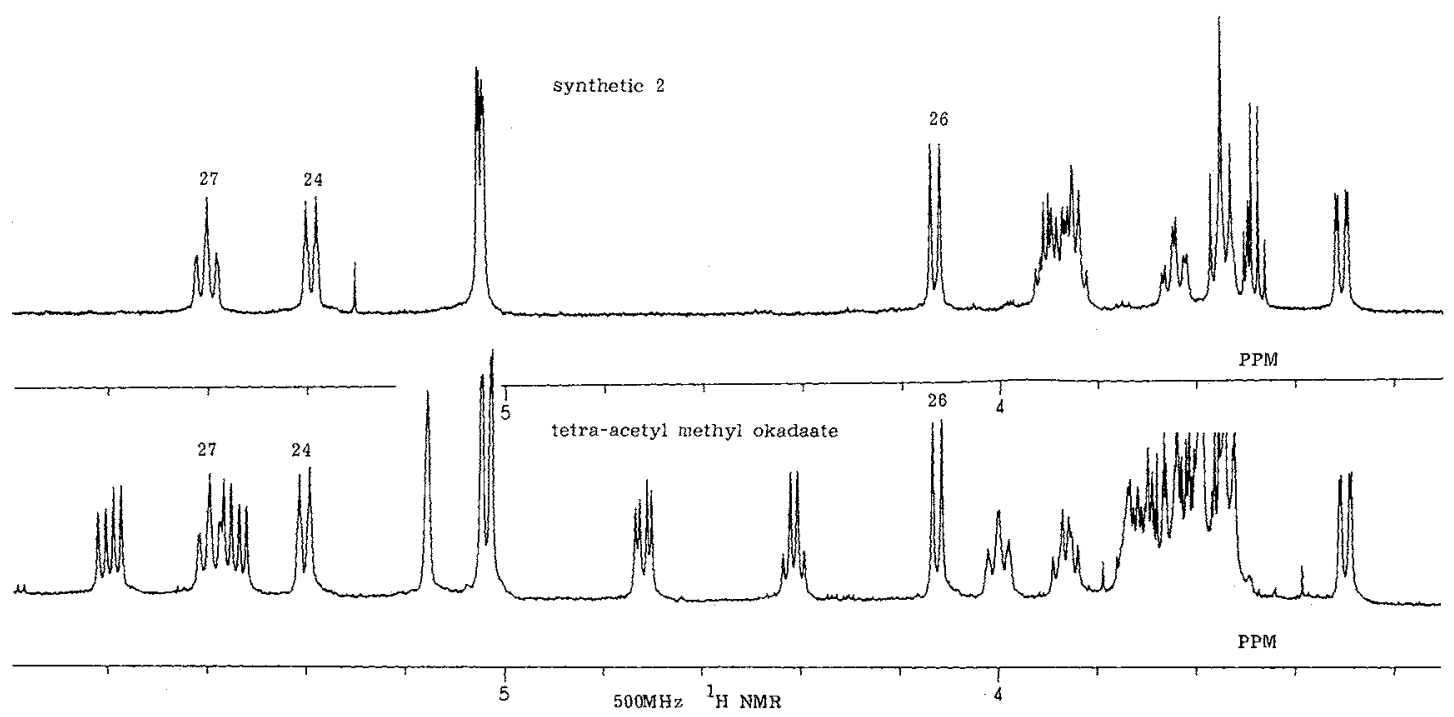

FIG. 1. ' ${ }^{1} \mathrm{H}-\mathrm{NMR}$ Spectra (in $\mathrm{CDCl}_{3}$ at $500 \mathrm{MHz}$ ) of Tetra-acetyl Okadaic Acid Methyl Ester 3 (Lower) and the Diacetate of $\mathrm{B} / \mathrm{C}$-Segment 2 (Upper). 
the tri-benzyl acetonide (4) with 38 carbon atoms and 17 asymmetric centers, which had been synthesized from D-glucose. ${ }^{3)}$ The authentic compound (4) was prepared as de- scribed in Scheme 1, and the stereochemisry including the $\mathrm{C}-27$ position was unambigously confirmed. The crucial step of this transformation involved i) selective protection of the

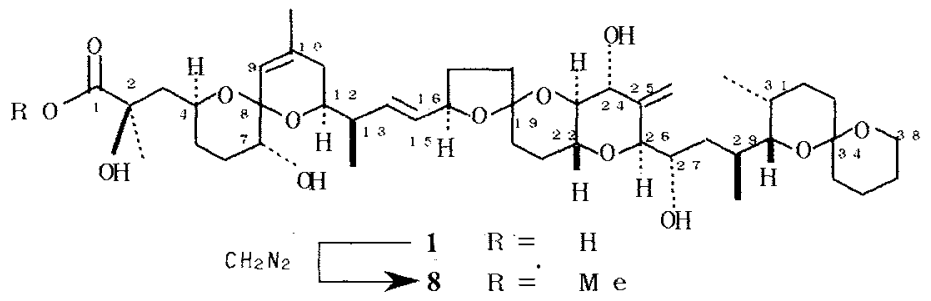

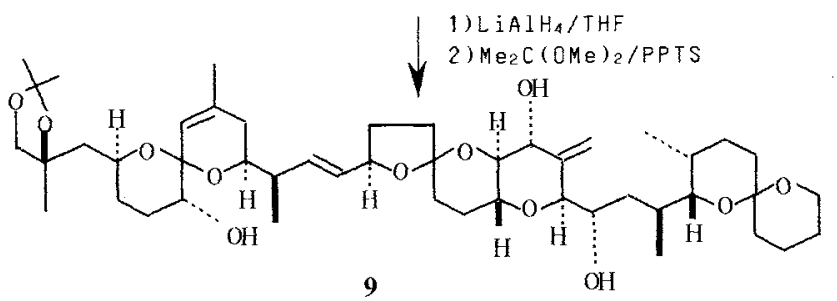

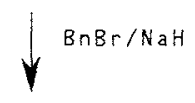

4

SCHEME 2.
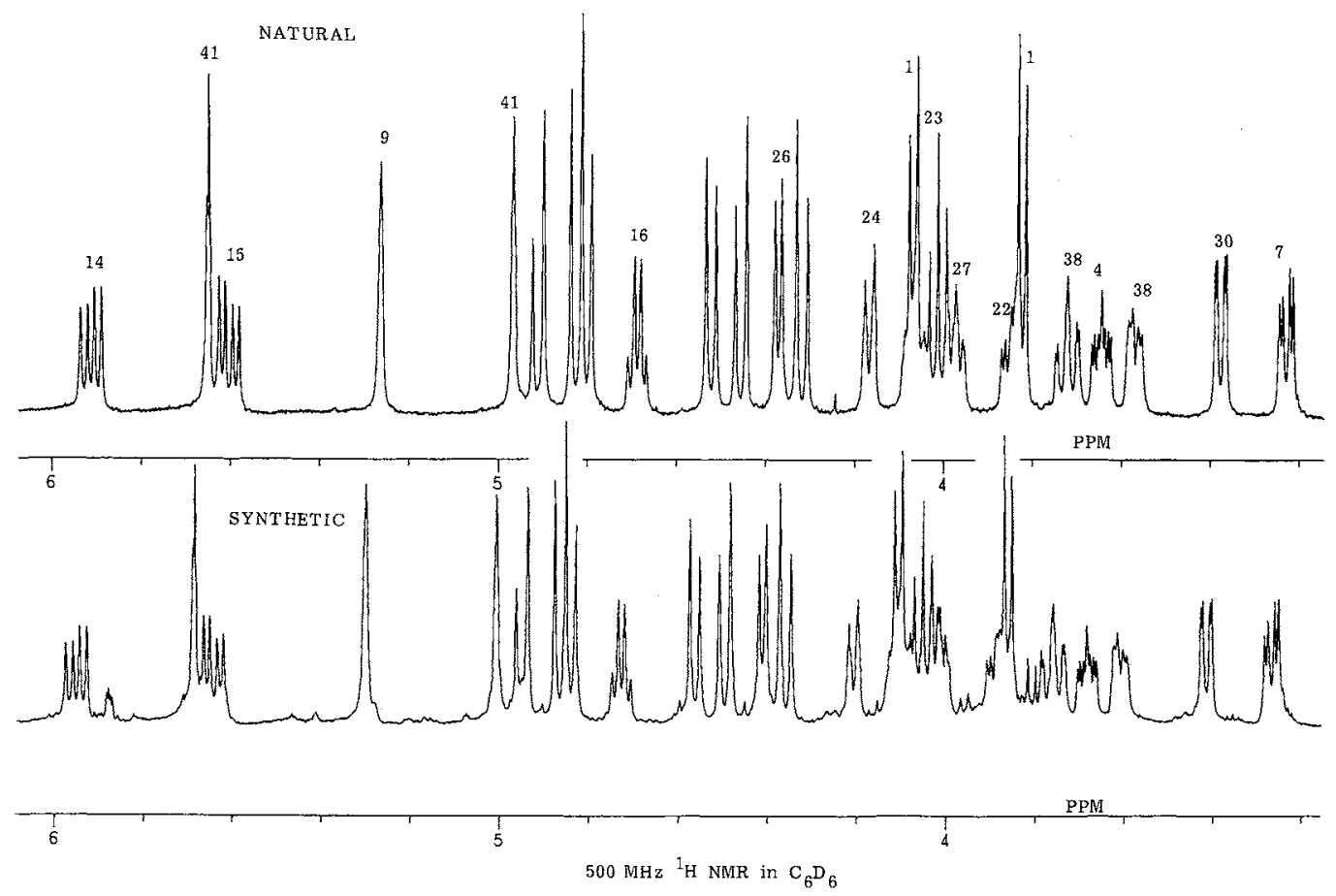

Fig. 2. ${ }^{1} \mathrm{H}$ NMR Spectra (in $\mathrm{C}_{6} \mathrm{D}_{6}$ at $500 \mathrm{MHz}$ ) of Synthetic (Lower) and Natural (Upper) Okadaic Acid. 
three hydroxy groups at C-7, C-24 and C-27 into the benzyl ether, and ii) transformation of the $\alpha$-hydroxy carboxylic group into the corresponding 1,2-diol and subsequent protection as its acetonide. Okadaic acid was benzylated with benzyl bromide and sodium hydride into the tribenzyl derivative (5). This was successively treated with diazomethane and then purified with chromatography to afford the tribenzyl methyl ester (6) in a $48 \%$ yield from okadaic acid. The ester moiety of 6 was reduced with lithium aluminum hydride (THF, $-78^{\circ} \mathrm{C}$ to $0^{\circ} \mathrm{C}$ ) to provide the tribenzyl diol (7) in a $60 \%$ yield. ${ }^{11)}$ This glycol was protected as its acetonide by treating with 2,2-dimethoxy propane in the presence of PPTS (pyridinium $p$-toluenesulfonate). ${ }^{12)}$ The tribenzyl acetonide (4) was obtained quantitatively. The overall yield through this sequence was only $29 \%$ from natural okadaic acid (1).

Since the preceding process was unsatisfactory in yield, the sequence in Scheme 2 was explored with a $66 \%$ overall yield. Okadaic acid was first treated with diazomethane (methanol, $0^{\circ} \mathrm{C}$ ) to provide the methyl ester (8). Reduction of the methyl ester with lithium aluminum hydride in tetranhydrofuran furnished the corresponding pentaol. The 1,2-diol moiety of this pentaol was protected with 2,2-dimethoxy propane in the presence of PPTS to afford only the acetonide triol (9). Finally, the triol (9) was protected as its benzyl ether (4) with sodium hydride and benzyl bromide in a mixture of tetrahydrofuran and $N, N$-dimethylformamide. ${ }^{11)}$ This tribenzyl acetonide (4) derived from natural okadaic acid was identical in all respects with those of the specimen that was synthesized in 102 steps from D-glucose $\left[500 \mathrm{MHz}{ }^{1} \mathrm{H}-\mathrm{NMR}\right.$ spectra measured in $\mathrm{CDCl}_{3}$ and $\mathrm{C}_{6} \mathrm{D}_{6},[\alpha]_{\mathrm{D}}=$ $+31.5^{\circ}\left(c=0.20, \mathrm{CHCl}_{3}\right.$, synthetic $) ;[\alpha]_{\mathrm{D}}=$ $+35.6^{\circ}(c=0.20$, natural)]. This molecule possessed 17 asymmetric centers, which were examined by the $500 \mathrm{MHz}{ }^{1} \mathrm{H}-\mathrm{NMR}$ spectrum measured in $\mathrm{C}_{6} \mathrm{D}_{6}$ (Fig. 2). All of the protons attached to the asymmetric centers were observed and assigned (see EXPERIMENTAL section). This result completely confirmed the stereochemistry at the $\mathrm{C}-27$ position $(\delta 4.01$ ppm, ddd, $J=10,2 \mathrm{~Hz}$ ) of the synthetic material.

The investigation of the transformation of okadaic acid just described supported our efforts that lead to the first total synthesis of okadaic acid in 106 steps from D-glucose. ${ }^{3)}$

\section{EXPERIMENTAL}

Proton nuclear magnetic resonance spectra were recorded on a JEOL GX-500 spectrometer. Chemical shifts are reported as values in parts per million relative to tetramethylsilane $(0.0 \mathrm{ppm})$ as an internal standard. All samples were dissolved in $\mathrm{CDCl}_{3}$ and recorded, unless otherwise described. Optical rotations were measured in 1$\mathrm{dm}$ cells of $2 \mathrm{ml}$ capacity by either JASCO MODEL DIP4 polarimeter or a JASCO DIP-181 digital polarimeter. Separation by TLC was made on plates with $0.5 \mathrm{~mm}$ precoated silica gel $\mathrm{PF}_{254}$ obtained from E. Merck (Art \#5744). Column chromatography was performed on silica gel supplied by Fuji Davison (BW-820 MH).

Tribenzyl okadaic acid (5). $\mathrm{NaH}(60 \%$ oil dispersion, $5 \mathrm{mg}$ ) was added to a solution of okadaic acid (1) $(8 \mathrm{mg}$, $0.010 \mathrm{mmol})$ and $\mathrm{BnBr}(18 \mu \mathrm{l}, 0.15 \mathrm{mmol})$ dissolved in a mixture of THF $(0.6 \mathrm{ml})$ and DMF $(0.1 \mathrm{ml})$, and the resulting mixture was stirred over night. A portion of water was added and the mixture was acidified with $1 \mathrm{~N}$ $\mathrm{HCl}$. The separated aqueous layer was extracted with $\mathrm{CH}_{2} \mathrm{Cl}_{2}$, and the combined organic layer was dried over $\mathrm{Na}_{2} \mathrm{SO}_{4}$. Evaporation of the solvent followed by purification on TLC gave the tribenzyl okadaic acid (5) (5 mg, 47\% yield $) .[\alpha]_{\mathrm{D}}=+48.1^{\circ}\left(c=0.31, \mathrm{CHCl}_{3}\right) ;{ }^{1} \mathrm{H}-\mathrm{NMR} \delta: 0.87$ $(3 \mathrm{H}, \mathrm{d}, J=7), 0.91(3 \mathrm{H}, \mathrm{d}, J=7), 1.05(3 \mathrm{H}, \mathrm{d}, J=7), 1.36$ $(3 \mathrm{H}, \mathrm{s}), 1.73(3 \mathrm{H}, \mathrm{s}), 2.13(1 \mathrm{H}, \mathrm{dd}, J=14,2), 2.23(1 \mathrm{H})$, $2.42(1 \mathrm{H}, \mathrm{qt}, J=7,7), 3.22(1 \mathrm{H}, \mathrm{dd}, J=11,2), 3.24(1 \mathrm{H}$, $\mathrm{dd}, J=12,4), 3.55 \sim 3.7(5 \mathrm{H}), 3.88 \sim 3.95(2 \mathrm{H}), 4.02(1 \mathrm{H}, \mathrm{tt}$, $J=11,2), 4.24(1 \mathrm{H}, \mathrm{d}, J=8), 4.48(1 \mathrm{H}, \mathrm{d}, J=13), 4.56(1 \mathrm{H}$, d, $J=11), 4.60(1 \mathrm{H}, \mathrm{d}, J=13), 4.61(1 \mathrm{H}), 4.73(1 \mathrm{H}, \mathrm{d}$, $J=11), 4.77(1 \mathrm{H}, \mathrm{d}, J=13), 4.89(1 \mathrm{H}, \mathrm{d}, J=13), 5.02(1 \mathrm{H}$, br.s), 5.14 (1 H, br.s), 5.17 (1H, br.s), $5.35(1 \mathrm{H}, \mathrm{t}, J=1)$, $5.61(1 \mathrm{H}, \mathrm{dd}, J=15,8), 5.74(1 \mathrm{H}, \mathrm{dd}, J=15,8)$. All other signals were left unresolved between $1.25 \sim 2.40 \mathrm{ppm}$.

Debenzylation of tribenzyl okadaic acid (5). A solution of tribenzyl okadaic acid $(5,3 \mathrm{mg})$ in $\mathrm{EtOH}(0.6 \mathrm{ml})$ and ammonia $(0.7 \mathrm{ml})$ was cooled to $-78^{\circ} \mathrm{C}$, and then Li metal (less than $1 \mathrm{mg}$ ) was added. After vigorous stirring at $-78^{\circ} \mathrm{C}$ for $30 \mathrm{~min}$, the cooling bath was removed, and the ammonia was allowed to evaporate. Water $(2 \mathrm{ml})$ was added, and the solution was then acidifed with $1 \mathrm{~N} \mathrm{HCl}$. The aqueous layer was extracted with $\mathrm{CH}_{2} \mathrm{Cl}_{2}$, and the combined organic layer was dried over $\mathrm{Na}_{2} \mathrm{SO}_{4}$ Evaporation of the solvent gave the crude okadaic acid. 
This was dissolved in $\mathrm{MeOH}(0.4 \mathrm{ml})$, and then treated with a solution of diazomethane prepared according to the procedure described by Fieser. ${ }^{13)}$ Purification of the resulting product on TLC provided okadaic acid methyl ester $(1.82 \mathrm{mg}, 80 \%$ yield), which was characterized by $500 \mathrm{MHz}$ ${ }^{1} \mathrm{H}-\mathrm{NMR}$.

Debenzylation of tribenzyl acetonide (4). To a solution of the tribenzyl acetonide derivative $(41 \mathrm{mg})$ in a mixture of EtOH $(0.3 \mathrm{mi})$ and ammonia $(0.6 \mathrm{ml}$, distilled from $\mathrm{Na}$ metal before use) that had been cooled to $-78^{\circ} \mathrm{C}$ was added $\mathrm{Li}$ metal $(1.37 \mathrm{mg})$, the solution being stirred vigorously. After stirring at $-78^{\circ} \mathrm{C}$ for $30 \mathrm{~min}$, the cooling bath was removed, and the ammonia was allowed to evaporate. Water was added, and the aqueous layer was extracted with $\mathrm{CH}_{2} \mathrm{Cl}_{2}$. The combined organic layer was dried over $\mathrm{Na}_{2} \mathrm{SO}_{4}$, and then evaporated to afford the triol (9), (1 mg) which was characterized by $500 \mathrm{MHz}{ }^{1} \mathrm{H}$ NMR.

Tribenzyl okadaic acid methyl ester (6). Okadaic acid (1 $11 \mathrm{mg}, 0.014 \mathrm{mmol}$ ) was converted into tribenzyl okadaic acid (5) with benzyl bromide $(20 \mu \mathrm{l}, 0.017 \mathrm{mmol}), \mathrm{NaH}$ $(60 \%$ oil dispersion, $7 \mathrm{mg})$, THF $(0.6 \mathrm{ml})$ and DMF $(0.15 \mathrm{ml})$. The resulting tribenzyl okadaic acid was dissolved in $\mathrm{MeOH}(0.4 \mathrm{ml})$ without purification. To this solution was added a solution of $\mathrm{CH}_{2} \mathrm{~N}_{2}$ at $0^{\circ} \mathrm{C}$ until TLC analysis showed the absence of the starting material. ${ }^{13)}$ Concentration of the solvent followed by chromatographic purification on $\mathrm{SiO}_{2}$ with ether-hexane ( $1: 3$ and $1: 1$ ) provided the tribenzyl okadaic acid methyl ester $(67 \mathrm{mg}, 48 \%$ yield $) .[\alpha]_{D}=+43.8^{\circ} \quad(c=0.36$, $\left.\mathrm{CHCl}_{3}\right) ;{ }^{1} \mathrm{H}-\mathrm{NMR} \delta: 0.88(3 \mathrm{H}, \mathrm{d}, J=7), 0.91(3 \mathrm{H}, \mathrm{d}$, $J=7), 1.07(3 \mathrm{H}, \mathrm{d}, J=7), 1.36(3 \mathrm{H}, \mathrm{s}), 1.71(3 \mathrm{H}, \mathrm{s})$, $3.2 \sim 3.27(2 \mathrm{H}), 3.57 \sim 3.75(5 \mathrm{H}), 3.70(3 \mathrm{H}, \mathrm{s}), 3.87 \sim$ $3.99(3 \mathrm{H}), 4.24(1 \mathrm{H}, \mathrm{d}, J=8), 4.47(1 \mathrm{H}, \mathrm{d}, J=12)$, $4.55(1 \mathrm{H}, \mathrm{q}, J=7), 4.55 \sim 4.61(2 \mathrm{H}), 4.74 \sim 4.84(4 \mathrm{H})$, 5.02 (1H, br. s), 5.15 (1H, br.s), $5.41(1 \mathrm{H}, \mathrm{t}, J=1), 5.56$ $(1 \mathrm{H}, \mathrm{dd}, J=15,7), 5.73(1 \mathrm{H}, \mathrm{dd}, J=15,8), 7.1 \sim 7.5$ $(15 \mathrm{H})$. All the other signals were left unresolved between $1.25 \sim 2.40$ ppm.

Tribenzyl diol (7). A solution of tribenzyl okadaic acid methyl ester (5) $(21 \mathrm{mg}, 0.020 \mathrm{mmol})$ dissolved in THF $(1.5 \mathrm{ml})$ was cooled to $-78^{\circ} \mathrm{C}$ in an $\mathrm{N}_{2}$ atmosphere, and then $\mathrm{LiAlH}_{4}$ in THF (1.2 $\mathrm{M}$ solution, $\left.0.1 \mathrm{ml}, 0.12 \mathrm{mmol}\right)$ was added dropwise. After stirring at $-78^{\circ} \mathrm{C}$ for $10 \mathrm{~min}$, the reaction mixture was gradually warmed up to $0^{\circ} \mathrm{C}$, before water ( 1 drop), $15 \%$ aq. $\mathrm{NaOH}$ ( 1 drop) and hexane $(1 \mathrm{ml})$ were added in this sequence. The solution was filtered and the filtrate cake was washed with EtOAc. Evaporation of the filtrate gave an oil $(20 \mathrm{mg})$, which was successively purified by chromatography on $\mathrm{SiO}_{2}$ with ether-hexane $(2: 1)$ as the eluant to provide the tribenzyl diol (7) (12 mg, $60 \%$ yield). $[\alpha]_{\mathrm{D}}=+34.1^{\circ} \quad(c=0.29$, $\left.\mathrm{CHCl}_{3}\right) ;{ }^{1} \mathrm{H}-\mathrm{NMR} \delta: 0.87(3 \mathrm{H}, \mathrm{d}, J=7), 0.90(3 \mathrm{H}, \mathrm{d}$, $J=6), 1.04(1 \mathrm{H}, \mathrm{d}, J=7), 1.13(3 \mathrm{H}, \mathrm{s}), 1.73(3 \mathrm{H}, \mathrm{s}), 2.47$
$(1 \mathrm{H}, \mathrm{qt}, J=7,7), 3.22(1 \mathrm{H}, \mathrm{dd}, J=10,2), 3.24(1 \mathrm{H}, \mathrm{dd}$, $J=12,4), 3.38 \sim 3.5(3 \mathrm{H}), 3.52(1 \mathrm{H}$, ddd, $J=11,9,3)$, $3.58 \sim 3.7(5 \mathrm{H}), 3.88 \sim 3.93(2 \mathrm{H}), 4.10(1 \mathrm{H}, \mathrm{tt}, J=11,2)$, $4.23(1 \mathrm{~h}, \mathrm{~d}, J=8), 4.47(1 \mathrm{H}, \mathrm{d}, J=13), 4.55(1 \mathrm{H}, \mathrm{d}, J=11)$, $4.58(1 \mathrm{H}), 4.61(1 \mathrm{H}, \mathrm{d}, J=13), 4.72(1 \mathrm{H}, \mathrm{d}, J=11), 4.73$ $(1 \mathrm{H}, \mathrm{d}, J=13), 4.82(1 \mathrm{H}, \mathrm{d}, J=13), 5.02(1 \mathrm{H}, \mathrm{br} . \mathrm{s}), 5.14$ (1H, br. s), $5.40(1 \mathrm{H}, \mathrm{t}, J=2), 5.60(1 \mathrm{H}, \mathrm{dd}, J=16.7), 5.85$ $(1 \mathrm{H}, \mathrm{dd}, J=16,7), 7.2 \sim 7.4(15 \mathrm{H})$.

Tribenzyl acetonide (4) from 7. To a solution of the diol (7 $2 \mathrm{mg}$ ) and PPTS (ca. $2 \mathrm{mg}$ ) in a mixture of $\mathrm{Me}_{2} \mathrm{C}=\mathrm{O}$ $(0.1 \mathrm{ml})$ and $\mathrm{CH}_{2} \mathrm{Cl}_{2}(0.3 \mathrm{ml})$ was added $\mathrm{Me}_{2} \mathrm{C}(\mathrm{OMe})_{2}$ $(500 \mu 1)$ dropwise. After stirring at room temperature for two hours, the solution was poured into aq. $\mathrm{NaHCO}_{3}$, and the aqueous layer was extracted with ether. The combined organic layer was washed with water and saturated aq. $\mathrm{NaCl}$, and dried over $\mathrm{Na}_{2} \mathrm{SO}_{4}$. Evaporation of the solvent gave the tribenzyl acetonide $(4,2 \mathrm{mg}$, quantitatively). $[\alpha]_{\mathrm{D}}=+35.6^{\circ}\left(c=0.20, \mathrm{CHCl}_{3}\right) ;{ }^{1} \mathrm{H}-\mathrm{NMR}$ (measured in $\left.\mathrm{C}_{6} \mathrm{D}_{6}\right) \delta: 1.00(3 \mathrm{H}, \mathrm{d}, J=7), 1.02(3 \mathrm{H}, \mathrm{d}, J=7), 1.13(3 \mathrm{H}$, $\mathrm{d}, J=7), 1.43(3 \mathrm{H}, \mathrm{s}), 1.49(3 \mathrm{H}, \mathrm{s}), 1.52(3 \mathrm{H}, \mathrm{s}), 1.53(3 \mathrm{H}$, s), $3.27(1 \mathrm{H}, \mathrm{dd}, J=12,4, \mathrm{H}-7), 3.41(1 \mathrm{H}, \mathrm{dd}, J=10,2, \mathrm{H}-$ $30), 3.61$ ( $1 \mathrm{H}, \mathrm{dd}, J=11,4, \mathrm{H}-38), 3.68$ ( $\mathrm{H}$, ddd, $J=11,7$, $3, \mathrm{H}-4), 3.76(1 \mathrm{H}, \mathrm{ddd}, J=13,11,3, \mathrm{H}-38), 3.86(1 \mathrm{H}, \mathrm{d}$, $J=9, \mathrm{H}-1), 3.88(1 \mathrm{H}, \mathrm{H}-22), 4.01(1 \mathrm{H}, \mathrm{ddd}, J=10,8,2, \mathrm{H}-$ 27), $4.05(1 \mathrm{H}, \mathrm{t}, J=10, \mathrm{H}-23), 4.11(1 \mathrm{H}, \mathrm{d}, J=9, \mathrm{H}-1), 4.1$ (1H, H-12), $4.21(1 \mathrm{H}, \mathrm{d}, J=10, \mathrm{H}-24), 4.36(1 \mathrm{H}, \mathrm{d}, J=13)$, $4.41(1 \mathrm{H}, \mathrm{d}, J=8, \mathrm{H}-26), 4.49(1 \mathrm{H}, \mathrm{d}, J=13), 4.56(1 \mathrm{H}, \mathrm{d}$, $J=11), 4.73(1 \mathrm{H}, \mathrm{q}, J=7, \mathrm{H}-16), 4.84(1 \mathrm{H}, \mathrm{d}, J=11), 4.86$ $(1 \mathrm{H}, \mathrm{d}, J=13), 4.95$ (1H, d, $J=13), 5.01$ (1 H, br.s, H-41), $5.30(1 \mathrm{H}, \mathrm{br}, \mathrm{s}, \mathrm{H}-9), 5.64(1 \mathrm{H}, \mathrm{dd}, J=16,7, \mathrm{H}-15), 5.69$ $(1 \mathrm{H}, \mathrm{t}, J=2, \mathrm{H}-41), 5.95$ (1H, dd, $J=16,8, \mathrm{H}-14), 7.1 \sim 7.5$ $(15 \mathrm{H})$. All the other signals were left unresolved between $1.2 \sim 2.4$ ppm.

Okadaic acid methyl ester (8). To a solution of okadaic acid (1) (10 mg) dissolved in $\mathrm{MeOH}(1 \mathrm{ml}$ ) that had been cooled to $0^{\circ} \mathrm{C}$ was added $\mathrm{CH}_{2} \mathrm{~N}_{2}$ (ether solution) dropwise until TLC analysis showed the absence of the starting material. The cooling bath was removed, and evaporation of the solvent provided the okadaic acid methyl ester $(\mathbf{8}$, $10 \mathrm{mg}$ ). This ester was used for subsequent reaction without further purification: $[\alpha]_{\mathrm{D}}=+27.2^{\circ}\left(c=0.10, \mathrm{CHCl}_{3}\right)$; ${ }^{1} \mathrm{H}-\mathrm{NMR} \delta: 0.93(3 \mathrm{H}, \mathrm{d}, J=7), 1.03(3 \mathrm{H}, \mathrm{d}, J=7), 1.07$ $(3 \mathrm{H}, \mathrm{d}, J=7), 1.36(3 \mathrm{H}, \mathrm{s}), 1.73(3 \mathrm{H}, \mathrm{s}), 3.29(1 \mathrm{H}, \mathrm{dd}$, $J=10,2), 3.42(1 \mathrm{H}, \mathrm{t}, J=9), 3.35 \sim 3.65(4 \mathrm{H}), 3.67(1 \mathrm{H}, \mathrm{td}$, $J=11,3), 3.82(3 \mathrm{H}, \mathrm{s}), 3.95(1 \mathrm{H}, \mathrm{d}, J=9), 3.95(1 \mathrm{H}$, br.t, $J=11), 4.09(1 \mathrm{H}, \mathrm{t}, J=10), 4.1 \sim 4.15(1 \mathrm{H}), 4.48(1 \mathrm{H}, \mathrm{td}$, $J=8,7), 4.95(1 \mathrm{H}, \mathrm{s}), 5.07(1 \mathrm{H}$, br. s), $5.33(1 \mathrm{H}, \mathrm{q}, J=1)$, $5.41(1 \mathrm{H}, \mathrm{t}, J=1), 5.47 \sim 5.57(2 \mathrm{H})$.

7,24,27-Triol-1,2-acetonide (9). To a solution of okadaic acid methyl ester $(5,10 \mathrm{mg})$ dissolved in THF $(1 \mathrm{ml})$ that had been cooled to $-78^{\circ} \mathrm{C}$ in an $\mathrm{N}_{2}$ atmosphere was added a solution of $\mathrm{LiAlH}_{4}$ in THF $(1.2 \mathrm{M}$ solution, $0.30 \mathrm{ml}, 0.36 \mathrm{mmol}$ ) dropwise. The reaction mixture was gradually warmed up to $0^{\circ} \mathrm{C}$, and then water ( 2 drops), 
$15 \%$ aq. $\mathrm{NaOH}$ ( 2 drops) and hexane $(0.7 \mathrm{ml})$ were added in this sequence. After stirring for $2 \mathrm{hr}$ at room temperature, $\mathrm{Na}_{2} \mathrm{SO}_{4}$ was added. The solution was filtered, and the filtrate cake was washed with EtOAc. The combined filtrate was concentrated under reduced pressure to afford the corresponding pentaol $(10 \mathrm{mg})$ as an oil. This pentaol was dissolved in $\mathrm{Me}_{2} \mathrm{C}=\mathrm{O}(2 \mathrm{ml})$, and $\mathrm{Me}_{2} \mathrm{C}(\mathrm{OMe})_{2}$ $(0.3 \mathrm{ml})$ and PPTS ( 2 crystals) were added. The reaction mixture was stirred at room temperature for $2 \mathrm{hr}$, and then poured into saturated aq. $\mathrm{NaHCO}_{3}$. The aqueous layer was extracted with $\mathrm{CH}_{2} \mathrm{Cl}_{2}$, and the combined organic layer was dried over $\mathrm{Na}_{2} \mathrm{SO}_{4}$. Evaporation of the solvent under reduced pressure gave the acetonide triol $(9,9 \mathrm{mg})$, which was used for subsequent reactions without further purification: $[\alpha]_{\mathrm{D}}=+5.3^{\circ}\left(c=0.076, \mathrm{CHCl}_{3}\right) ;{ }^{1} \mathrm{H}-\mathrm{NMR} \delta$ : $0.93(3 \mathrm{H}, \mathrm{d}, J=7), 1.06(3 \mathrm{H}, \mathrm{d}, J=7), 1.09(3 \mathrm{H}, \mathrm{d}, J=7)$, $1.29(3 \mathrm{H}, \mathrm{s}), 1.33(3 \mathrm{H}, \mathrm{s}), 1.39(3 \mathrm{H}, \mathrm{s}), 1.75(3 \mathrm{H}, \mathrm{s}), 3.29$ $(\mathrm{lH}, \mathrm{dd}, J=10,2), 3.39(1 \mathrm{H}, \mathrm{dd}, J=11,4), 3.46(1 \mathrm{H}, \mathrm{t}$, $J=10), 3.53 \sim 3.61(2 \mathrm{H}), 3.62 \sim 3.70(2 \mathrm{H}), 3.69(1 \mathrm{H}, \mathrm{d}$, $J=9), 3.84(1 \mathrm{H}, \mathrm{d}, J=9), 3.8 \sim 3.85(1 \mathrm{H}), 3.94(1 \mathrm{H}, \mathrm{d}$, $J=10), 4.08(1 \mathrm{H}$, br. $t, J=10), 4.16(1 \mathrm{H}$, br. d, $J=10), 4.48$ $(1 \mathrm{H}, \mathrm{q}, J=7), 5.08$ (1H, br.s), 5.31 (1H, br. s), $5.41(1 \mathrm{H}, \mathrm{t}$, $J=1), 5.52(1 \mathrm{H}, \mathrm{dd}, J=16,7), 5.75(1 \mathrm{H}, \mathrm{dd}, J=16,8)$.

Tribenzyl acetonide (4) from 9. To a suspension of $\mathrm{NaH}$ ( $5 \mathrm{mg}$, washed with hexane before use) in $\mathrm{THF}(0.7 \mathrm{ml})$ was added a solution of acetonide triol (9) in THF $(0.2 \mathrm{ml})$ dropwise. After stirring at room temperature for $30 \mathrm{~min}$, $\mathrm{BnBr}(20 \mu \mathrm{l})$ and DMF $(0.2 \mathrm{ml})$ were added, and stirring was continued for $30 \mathrm{hr}$. The reaction mixture was poured into water and the separated aqueous layer was extracted with ether. The combined organic layer was washed with water and saturated aq. $\mathrm{NaCl}$, and dried over $\mathrm{Na}_{2} \mathrm{SO}_{4}$. Evaporation of the solvent gave an oil, which was successively purified by chromatography on silica gel $(4 \mathrm{~g})$ with ether-hexane $(1: 2)$ as the eluant to provide tribenzyl acetonide $(4,9 \mathrm{mg})$ in a $66 \%$ overall yield starting from okadaic acid (4 steps).

Acknowledgments. We thank Professor D. Uemura (Shizuoka Univ.) and Professor Y. Hirata (Meijo Univ.) for their kind gift of okadaic acid. Part of this work was supported by the Naito Science Foundation.

\section{REFERENCES AND NOTES}

1) K. Tachibana, P. J. Scheuer, Y. Tsukitani, H. Kikuchi, D. V. Engen, J. Clardy, Y. Gopichand and F. Schmitz, J. Am. Chem. Soc., 103, 2469 (1981).

2) M. Murata, M. Shimatani, H. Sugitani, Y. Oshima and T. Yasumoto, Bull. Japan. Soc. Sci. Fish., 48, 549 (1982); T. Yasumoto, M. Murata, Y. Oshima, M. Sano, G. K. Matsumoto and J. Clardy, Tetrahedron, 41, 1019 (1985).

3) M. Isobe, Y. Ichikawa and T. Goto, Tetrahedron Lett., 27, 963 (1986).

4) T. W. Greene, "Protective Groups in Organic Synthesis," John Weily \& Sons, New York, 1981.

5) The resulting okadaic acid showed a partially different ${ }^{1} \mathrm{H}$ NMR spectrum from that of the starting okadaic acid. Namely, the resulting product did not show the peak at $\delta 5.78 \mathrm{ppm}(1 \mathrm{H}$, br. s), which was assigned to be the proton of either carboxylic acid or the hydroxy groups. Some impurities seem to have prevented this peak from apprearing in this region.

6) This okadaic acid specimen showed the peak at $\delta$ $5.78 \mathrm{ppm}$.

7) a) M. Isobe, Y. Ichikawa; H. Masaki and T. Goto, Tetrahedron Lett., 25, 3607 (1984); b) M. Isobe, Y. Ichikawa, D. Bai and T. Goto, ibid, 26, 5199 (1985); c) M. Isobe, Y. Ichikawa and T. Goto, ibid., 26, 5203 (1985); d) Y. Ichikawa, M. Isobe, D. Bai and T. Goto, Tetrahedron, 43, 4737 (1987); e) Y. Ichikawa, M. Isobe and T. Goto, ibid., 43, 4749 (1987); f) Y. Ichikawa, M. Isobe, H. Masaki and T. Goto, ibid., 43, 4759 (1987); g) M. Isobe, Y. Ichikawa, D. Bai, H. Masaki and T. Goto, ibid., 43, 4767 (1987).

8) M. Cherest, H. Felkin and N. Prudent, Tetrahedron Lett., 1968, 2199; T. A. Nguen and U. Eisenstein, Nouv. J. Chim., 1, 61 (1977).

9) K. Tachibana, Ph.D. Dissertation, University of Hawaii, Honolulu, U.S.A., 1980.

10) Y. Ichikawa, M. Isobe and T. Goto, Tetrahedron Lett., 25, 5049 (1984).

11) ${ }^{1} \mathrm{H}$ NMR spectra of the two samples of the acetonide tribenzyl (via Schemes I and II) were identical.

12) M. Miyashita, A. Yoshikoshi and P. A. Grieco, $J$. Org. Chem., 42, 3772 (1977).

13) L. F. Fieser and M. Fieser, "Reagents for Organic Synthesis," John Weily \& Sons, New York, 1967, p. 191. 